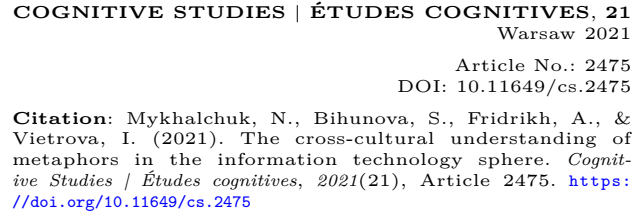

\author{
Natalia Mykhalchuk $\left(\mathbb{D}\right.$, Svitozara Bihunova $\mathbb{D}^{\mathbb{D}}$, Alla Fridrikh $\left(\mathbb{D}\right.$, Iryna Vietrova ${ }^{(\mathbb{D}}$ \\ Rivne State University of the Humanities, Rivne, Ukraine \\ \{nataliia.mykhalchuk, svitozara.bihunova, alla.fridrikh, iryna.vietrova\}@rshu.edu.ua
}

\title{
The Cross-Cultural Understanding of Metaphors in the Information Technology Sphere
}

\begin{abstract}
This paper analyses recent changes in cross-cultural communication concerning metaphor use and its functioning on the Internet, specifically in the information technology sphere.

The paper outlines the academic literature and proposes a study that aims to evaluate users' perception of IT metaphors. The study analyses reports and articles for IT users. The articles were profiled according to country and language, with a detailed analysis of English and Ukrainian examples. The paper reviews the relation between IT metaphors and their cognition, introducing a new conceptualization "A Computer as a Human Being". The research seeks to provide evidence for the claim that understanding metaphors facilitates cross-cultural communication, whether universal or culturally-bounded.

The results show the growing scale of the creation of new metaphors due to cross-cultural communication, especially in the IT sphere, and the importance of the cognitive functions of metaphors in a culturally and linguistically diverse environment.
\end{abstract}

Keywords: conceptual metaphor theory; information technology; metaphor; metaphorization; cross-cultural communication

\section{Introduction}

The whole history of humanity is a cognitive process of experiencing and uniquely understanding the world. Language serves as a bridge between the world and its cognition. Different theories exist in the literature regarding the link between language and reality, and the study by A. Ortony (1993) offers probably the most comprehensive understanding of the relationship between them. In the follow-up study, A. Ortony (1993) pointed out that language itself is a part of reality. Significant analysis and discussion on the subject were presented by T. Colburn \& G. Shute (Colburn \& Shute, 2007), who demonstrated how language contributes to our knowledge of reality through metaphor.

It remains beyond doubt that we use language to study the world, but contemporary reality is complex due to constant and rapid change, and our range of cognition has both extended and deepened. Consequently, original categories may no longer reflect the dynamic and rapidly changing world. Accordingly, new concepts occur in languages in different spheres, especially in the information technology (IT) sphere. Today, the language of IT is laced with metaphors which are omnipresent and common in our everyday life, not only in the professional sphere.

The academic literature on metaphor has highlighted several theories which attempt to answer the theoretical question of what metaphors are. It has revealed the emergence of several contrasting views (Ortony, 1993). In his study of the semantics of metaphor, L. Cohen (1993) defines 
metaphors to be a purely linguistic phenomenon and points out that metaphorical meaning can arise directly from literal meaning through a set of linguistic rules. A study by J. Searle (1993) proposes that metaphors are a general communication phenomenon associated with languages. Significant analysis and discussion on the subject were presented by G. Lakoff, who claims that metaphors are involved in the general phenomenon of thought and mental representation (Lakoff, 1993).

A huge variety of attempts to define the essence of metaphors has long been the focus of increased attention among researchers (Aristotel', 2000; Blèk, 1990; Eco, 1984; Gibbs \& Matlock, 2010; Indurkhya, 1992; Kövecses, 2002, 2015; Lakoff, 1987; Lakoff \& Johnson, 1980; Ortony, 1993; Thibodeau \& Boroditsky, 2013 and many others). In our work, we follow Indurkhya, who characterizes metaphor as "a description of an object or event, real or imagined, using concepts that cannot be applied to the object or event in a conventional way" (Indurkhya, 1992, p. 18).

Metaphors in the IT sphere are a good example to support Indurkhya's definition. For instance, a "desktop", reminiscent of a real desk with folders and papers, can be applied to a real object. However, when operating "virtual documents" ("windows", "screens", etc.) users associate an abstract object ("file", "document") with a variety of available tools in their hierarchy or interrelations. In Windows, the interface contains such abstract objects as registries, pages, files, and folders (even here there is an element of confusion, since "file" in Ukrainian literally means "a filing of papers" ([papka, dos'e, dokument], which is to say, a folder). Operating systems run servers and clients, applications execute threads, download data, clean garbage, and experience memory leaks while we use displays (segments of the screen) with windows, buttons, tabs, and menus. Users regularly perform streaming, meetings, online shopping. They use web money and shopping carts, and surf the net, searching for information in virtual reality. Many of the IT metaphors listed above are abstractions to some extent and cannot be applied to a certain object or event. The study by T. Colburn and G. Shute (Colburn \& Shute, 2007) offers probably the most comprehensive analysis of the role that abstraction plays in computer science.

Technological progress, globalization, and enhanced virtual communication are responsible for significant changes in the emergence of metaphors in IT and everyday life. Hence, the characterization of metaphors is valuable for our increased understanding of cross-cultural communication. In addition to ongoing internationalization and global networking, worldwide IT activity has reached a very high degree of synchronicity (Bogachyk \& Bihunov, 2020).

A growing body of cognitive science research on meaning, conceptualization, reasoning, and language has led to a redefining of the nature, role, and functioning of metaphors. G. Lakoff and M. Johnson discovered that metaphor is conceptual rather than linguistic and that most metaphorical thought is not based on perceived similarities in the world. They insist that conceptual metaphors are frame-to-frame mappings, where frames are basic structures of everyday thought. Conceptual metaphors thus consist of "source domain" frames that are mapped onto "target domain" frames, with most of the inference structure found in the source domain carried over to the corresponding target-domain structure (Lakoff \& Johnson, 1980). Linguistic and psychological methods of inquiry continue to shed new light on how metaphors are learned, how they structure conceptual systems, and how they shape our reasoning in all aspects of our lives.

Scholars are examining the functioning of metaphors in languages and cultures across the world. Researchers are trying to study various perspectives on the issue, e.g. a comparative analysis of verbal synesthetic metaphors in Polish and English (Zawisławska \& Falkowska, 2018); an explication of the meanings of expressions representing a specific type of genitive metaphor (Szymańska, 2018); understanding and producing metaphors in order to develop learners' sociolinguistic, illocutionary, grammatical, discourse, and strategic competence (Littlemore \& Low, 2006a, 2006b); the existence, application, and function of metaphors in specialist scientific discourse (Knudsen, 2003); the necessity of creating new metaphors and new ways of describing and thinking about the future (Wyatt, 2021). Metaphors have moved from the margins to the centre of the study of cognition, thought, and language and have been recognized as a fundamental process of human cognition, conceptualization, and reasoning. As a result, new impetus has been given to 
conceptual metaphor because of its crucial role in achieving effective cross-cultural communication. When communication occurs between people who do not belong to the same culture and thus do not share knowledge, values, and assumptions, reaching mutual understanding can be especially difficult. In such cases, mutual understanding is achievable only when discussing meaning. Thus, the possession of an imagination based on metaphors is a crucial ability in establishing mutual understanding and conveying to an interlocutor the essence of one's individual experience. This ability provides the possibility to change one's world view and to acquire a new categorization of experience.

The increased use of online communication, caused by lockdown restrictions related to the global Covid-19 pandemic, has raised the importance of IT language awareness among all users. This is why IT-related articles are appropriate for metaphor research. The need to systematically use metaphors in IT articles is explained by the fact that these texts are today written by experts who need to express complicated and abstract phenomena in a concise and quickly understandable way to non-specialized readers. We have attempted to define the interrelationship which can be found between universal and culturally bound constructs, having analysed the empirical material with data gathered via journals.

The research provides an account of the interrelationship between metaphors and creativity in their interpretation. It focuses on different characteristics and functions that emerge during metaphor comprehension, and how significantly figurative meaning contributes to its cognition. The human mind is selective when processing information and this often leads to the creation of new "ad hoc" metaphors.

We aim to analyse metaphorical processes from an interlinguistic and intercultural perspective. Our goal is to examine metaphors in English and Ukrainian articles dealing with IT to determine whether metaphors facilitate or impair communication and how people from various cultural backgrounds endeavour to communicate across cultures. The examples of Ukrainian interpretation given in the case study help to understand not only what people of different nationalities have in common, but also to define the diversity which underlies the language and the reality we live in. In addition to this, the study attempts to indicate the key role that metaphor plays for the cognition of abstraction in facilitating virtual reality, programming languages, operating systems, etc. Another aim is to establish in what ways and to what extent metaphors can lead us to an understanding of the world around us, society, and culture, i.e. what user-friendly effect can be achieved by metaphors.

\section{Theoretical Framework}

Cognitive linguists have done important work on universal aspects of metaphor. Zoltán Kövecses has devoted much attention to the question of why metaphors vary both interculturally and intra-culturally as extensively as they do (Kövecses, 2015). In the issue of the degree of cultural coherence in the interplay among conceptual metaphors, we follow Kövecses, who has identified the major dimensions of metaphor variation, that is, those social and cultural boundaries that signal discontinuities in human experience.

We presume that IT metaphors are based on both pre-existing and emerging similarities between computing and traditional domains. Owing to the peculiar status of IT in cross-cultural communication, the role of similarity in metaphorical attribution is multifaceted and multidimensional. It has therefore been the subject of study of many research disciplines such as philosophy, linguistics, psychology, cognitive linguistics, lexicology, cultural linguistics, and others. The number of disciplines is still expanding. The main idea of cognitive linguistics, according to $\mathrm{M}$. P. Kocherhan (2010, p. 149), is that the language capacity of a human is a part of his/her cognitive ability. Therefore, anthropocentrism has become one of the main tasks of this science. Studying metaphors plays a significant role in the cognitive processes which occur in the human mind when encoding and decoding speech. This process, in turn, emphasizes the important role of metaphor 
as an example of the close connection between language and cognition. Thus, the dual nature of metaphor as a stylistic means of language, on the one hand, and a deep cognitive process, on the other hand, explains the inexhaustible interest in this phenomenon. G. Lakoff and M. Johnson point out that the great interest in metaphor has arisen because it structures our perception, way of thinking, and activity (Lakoff \& Johnson, 1980).

Metaphors are deep concepts of human consciousness which influence a person's perception of the surrounding world. In the work Women, Fire and Dangerous Things, G. Lakoff interprets metaphor as a transfer of a cognitive structure that is prototypically associated with a particular language embodiment from one area to which it belongs to another one (Lakoff, 1987). Embodied cognition accounts posit that concepts are grounded in our experience. The challenge is to explain how abstract concepts, which do not draw on the experience, can be informed. Metaphor is an essential item guiding the development and use of abstract concepts. Metaphors allow us to draw on concrete, familiar domains to reach cognition and to understand their abstract meaning.

People do not only express their ideas and thoughts with metaphors, but also think with their help, discovering the surrounding world. Earl R. Cormac, in his work A Cognitive Theory of Metaphor, defines metaphors as a cognitive way of thinking and writes that metaphors function as cognitive processes through which people deepen their understanding of the world. He also notes that metaphors function as mediators between the human mind and culture. New metaphors transform everyday language and simultaneously change the ways in which people perceive and comprehend the world (Mac Cormac, 1990).

Moreover, Jose Ortega y Gasset explains that not all objects are easily accessible to our thinking and we cannot form a separate, clear, and precise idea about everything. Therefore, we need metaphors to make new objects more accessible to our thoughts. We start using metaphors as instruments of thought, so-called "bridges" between well-known ideas or objects to those which are complicated and difficult to understand, and subsequently we manage to form ideas about those complex objects (Ortega y Gasset, 1966).

According to Nina Arutyunova, metaphor is an opportunity to convey the individuality and uniqueness of a particular object or phenomenon. She claims that in the process of perceiving the world metaphor is a means of creating an image from which it can also turn into a way of forming meanings that language lacks (Arutiunova, 1979).

Metaphors, Paul Ricoeur states, reproduce fragments of the social experience of a certain cultural community and noticeably create this experience. He emphasizes that new metaphors create a new reality and that if new metaphors become a part of the conceptual system that serves as the basis for our reality, they will change the system, as well as the ideas and actions it generates (Ricoeur, 2003). In this manner, metaphorization is possible due to the ability of a person to compare his or her own experience with new unfamiliar concepts.

The nominative function of metaphor is often manifested in scientific language. Max Black considers that the purpose of metaphors is either for speech decoration or for naming a phenomenon that has no suitable literal expression. In the latter case, metaphor is often used in science to create new terms and concepts (Blèk, 1990).

Rita Temmerman (2000) is convinced that metaphoric thinking is obligatory for scientists as it helps them to understand, describe and explain new ideas or facts in various research disciplines. In her book Towards New Ways of Terminology Description: The Socio-cognitive Approach, she advocates specialists' creative thinking and has no doubts that metaphor has significant productivity in term creation. Moreover, the author differentiates two types of metaphors - didactic metaphors and creative metaphors. Didactic metaphors are used for teaching situations, the latter create neologisms, which become new technical terms which make specialized scientific texts easier for non-specialists to understand (Temmerman, 2000).

Adhering to previous research findings, we may suppose that the creation of new terms looks as follows: Firstly, a person correlates a new phenomenon with existing experience and analyses the received information using images and concepts available on a cognitive basis. As mentioned above, the ability to imagine the unknown with the help of already familiar ideas, objects, or 
concepts leads to the understanding of a new one. Secondly, the usage of a metaphor facilitates the term formation and leads to better adaptation to the language. Moreover, as metaphorization occurs based on either the native language or international words that are already widely used in this language, using a newly-born metaphor will require no special effort in terms of memorization. What is more, a newly-formed metaphor loses its ambiguity and expressiveness, but the transparency of its motivation leads to an active understanding of abstract concepts.

\section{Empirical Analysis}

Metaphors have long been used in the information technology (IT) domain to explain innovations, communicate complex concepts, and describe challenging technologies. The matter under study is determined from a cross-cultural perspective, taking into account differences and similarities between the source culture and the target culture. The research subject is not only language for special purposes (LSP), but the IT corpus in general. This corpus is a perfect basis for empirical studies insofar as it is not only LSP but reflects current usage. The relevance of the cognitive theory of metaphor for intercultural aspects begins with its principle of ubiquity, which is considered to be the most important (Schmidt, 2009). This means that metaphorical concepts should be used in ordinary situations to denote norms, express values, define activities, and verbalize emotions etc (Knudsen, 2003; Mykhalchuk \& Bihunova, 2019). From a cross-cultural perspective, two more items should be taken into consideration. The first is the metaphorical concept, which uses certain ways of experiencing the world to denote abstract objects or processes. When expressing abstract notions, people use one aspect of the domain of origin, not every aspect. This is the main principle of culture-bound ways of mapping concepts. The second item to be taken into account is that metaphors work unilaterally from concrete images of experiencing the world to abstract notions.

3.1.1 Phase 1 - Analysis of IT Metaphors The first step in this study was to locate the source domains of IT metaphors in two languages: English and Ukrainian. All the texts in the two languages use images to express abstract and complicated events and notions in the IT sphere of the same metaphorical concept. Adhering to these ideas, we attempted to categorize metaphors in the IT sphere according to associations based on the following signs: shape similarity, function similarity, similarity of form and function, location similarity, and similarity of properties (differential features), as presented in Table 1.

Based on this classification, we have tried to clarify the proposed similarities. For this purpose we have designed the concept scheme "A Computer as a Human Being" (cf. Figure 1), in which we listed these similarities with a human being.

As mentioned above, metaphor creation and comprehension are determined by language users' experience and imagination, which are related to language users' spheres of activity. There is a deeper and more important relation between metaphor and cognition: a metaphor is no longer a passive process of realizing our enlarging knowledge. Instead, it helps us to gain new knowledge and to get to know the objective world more deeply. The examples are interpreted into Ukrainian to make them clear to Ukrainian readers. This facilitates readers' understanding of the conceptual logic from the source domain used in the two languages for constructing metaphors.

For instance, the medical term "virus" [virus] is now used in computer science and IT. This metaphor quickly and painlessly substituted and recalled a computer "worm", which is a type of standalone computer program that replicates itself to spread to other computers. This metaphor was first used in a headline in The San Francisco Chronicle, in an article from 5 November 1988: "Vicious 'Worm' Spreads Havoc Through Computers in U.S.". After this appearance, malicious programs were called "worms" or "viruses" (Gozzi, 1990). The comparison is based on function similarity, in particular: adverse impact. The metaphor "vaccine" [vaktsyna] appeared later in the IT sphere to denote the treatment of a computer virus. 
Table 1. Classification of metaphorical IT terms based on similarity.

\begin{tabular}{|c|c|}
\hline $\begin{array}{c}\text { The similarity } \\
\text { in metaphorical } \\
\text { terms }\end{array}$ & Examples in the IT sphere \\
\hline $\begin{array}{l}\text { 1. Similar in } \\
\text { name, shape, } \\
\text { essential char- } \\
\text { acteristics }\end{array}$ & $\begin{array}{l}\text { Archie, data glove, power glove, data tablet, electronic tablet, eyephone, gopher, } \\
\text { spider, joystick, jukebox, laser printer, touch tablet, Veronica, viewdata, mother- } \\
\text { board, agent, anchor, applet, bloatware, bogusware, browser, careware, cancelbot, } \\
\text { charityware, crippleware, cruncher, data cruncher, courseware, donorware, firmware, } \\
\text { fontware, firewall, FTP client, FTP server, interface agent, killer app, knowbot, leg- } \\
\text { acy code, legacy software, legacy system, middleware, spell checker, systems soft- } \\
\text { ware, toggle, virus scanner, Web crawler, Web spider, wetware, anti-viral, desktop- } \\
\text { centric, downloadable, FTPable, glitchy, menu-driven, mouse-controlled, preloaded, } \\
\text { pulldown, vanilla, computer virus, Michelangelo (virus, activating annually on March, } \\
\text { 8, the birthday of artist Michelangelo), stealth virus, worms, a Trojan, Trojan horses, } \\
\text { cloud, hard drive, cloud computing, superhighway, mouse, window, icon, folder }\end{array}$ \\
\hline $\begin{array}{l}\text { 2. Activity } \\
\text { similarity }\end{array}$ & $\begin{array}{l}\text { Adventure gaming, authoring, crunch, flaming, hacking, netsurfing, spamming, surf } \\
\text { the net, telecommuting, teleconferencing, telecottaging, trolling, work grouping, } \\
\text { zooming, googling, teleshopping, teleordering, telemarketing, electronic banking, } \\
\text { home banking, telebanking, telebetting, telebroking, virtual shopping. }\end{array}$ \\
\hline $\begin{array}{l}\text { 3. Similarity } \\
\text { of forms and } \\
\text { functions }\end{array}$ & $\begin{array}{l}\text { Capture, browse, caching, data capture, download, downloading, downsizing, FT- } \\
\text { Ping, upload, uploading, electronic document, electronic text, e-text, FAQ, hyperfic- } \\
\text { tional, hypertext, hypertextual, scrollable, sig, teletext, Web page, word-wrap, drop- } \\
\text { up menu, main menu, menu, menu-bar, pop-up menu, scroll-bar, submenu, toggle. }\end{array}$ \\
\hline $\begin{array}{l}\text { 4. Location } \\
\text { similarity }\end{array}$ & $\begin{array}{l}\text { Telecottage, televillage, telecentre, virtual classroom, virtual office, electronic news- } \\
\text { room, smart building, smart house. }\end{array}$ \\
\hline $\begin{array}{l}\text { Similarity } \\
\text { of properties }\end{array}$ & $\begin{array}{l}\text { Data warehousing, slice-and-dice, dataflow, tooltip, gopherspace, package, software } \\
\text { package, toolkit, toolset, toolbar, logic bombs, millennium bug. }\end{array}$ \\
\hline
\end{tabular}

The term "superhighway" [informatsiina supermahistral'] in the sphere of transport now denotes an information highway in IT. The information superhighway facilitates the exchange of information and can also contribute to the development and the promotion of public awareness worldwide. It is a metaphor based on a comparison of characteristics and features.

The metaphor "cloud" $[k h m a r a]$ refers to servers that are accessed via the Internet and software, and databases that run on these servers ("cloud computing", "cloud download"). It can be compared with weather, namely a visible mass of condensed water vapor floating in the atmosphere. "Cloud computing" means storing and accessing data over the Internet instead of one's computer "hard drive" [zhorstky̌ dysk]. A fundamental concept behind "cloud computing" is that the location of the service is irrelevant to the user. The metaphor "cloud" was borrowed from old telecoms network schematics, in which the public telephone network (and later the internet) was often represented as a cloud to denote that it did not matter - it was merely an intangible cloud. The use of cloud computing has enabled the internet to become so prominent in everyday life. Ultimately, the "cloud" is a metaphor based on a comparison of location.

The metaphor "to surf the net" [korystuvatysia internetom, serfinh $v$ merezhi] means an easy and quick way to find any information through the internet by moving from page to page or site to site on the World Wide Web. This metaphor was created through the comparison with surfing, the sport or pastime of riding a wave towards the shore. The most logical starting point for comparison, in this case, is human activity.

More examples: "desktop" [robochy̆ stil] with "icons" [znachky, ikonky na robochomu stoli] and the "start menu" [startove meniu]. These three items have also become metaphors in the IT sphere. A desktop refers to the working area of a computer screen, regarded as the presentation of 
a notional desktop, containing icons representing items such as files. Let us analyse the following sentence: "You can have multiple, overlapping windows on the desktop". In this case, we relate "window" [vikno] to IT and understand it not as an opening in the wall of a building or a vehicle, but as a means of obtaining information. The metaphorized notion "folder" [papka, systemny kataloh] is understood as a place on a computer where files or programs can be stored. Originally, however, it was a piece of plastic or cardboard used for storing loose papers. The comparison is based on the similarity of use and function.

In IT, "anchor" [iakir] or "boat anchor" is something obsolete, useless, and cumbersome so-called metaphorically because the only productive use of it is to be thrown into the water as a boat mooring. Metaphors such as "brick", "doorstop", and "paperweight" are similar. Early computers were large and heavy devices. As computers became more compact, the metaphor "boat anchor" became popular among users to signify that the previous larger computer gear was obsolete, useless, or even damaged. The metaphor "anchor" has been extended to software code that is left in a system's codebase, in case it is needed later. This comparison is based on the similarity of characteristics and peculiarities.

Two ways of creating metaphors in the IT sphere can be distinguished. The first is the use of common words and expressions in a figurative sense, according to the principle of similarity (appearance, structure, functions, etc.). New associative links occur due to new rules. For instance, well-known and widely used among computer users are the terms "mouse" [myshka] (a computer device, transfer of meaning by appearance), "window" [vikno] (the operating system, transfer of meaning by function), "virus" [virus], etc.

Metaphors from everyday language are actively used in technical terminology. For example, a common expression is "to build a program" [vybudovuvaty prohramu]. The direct meaning of the word "build" is substituted by the figurative meaning. In general, terms of this type evoke certain associations and are easy to remember and understand.

In the professional IT sphere, some terms represent a metaphorical transfer. For example, the term "cookie(s)", which refers to small pieces of data received by a computer from a browser and stored to identify a user, translates in common language as [pechyvo]. The etymology of the term indicates that in the 1990s "magic cookies" [mahichne pechyvo] referred to packets of information that were convenient for the purposes of online purchases

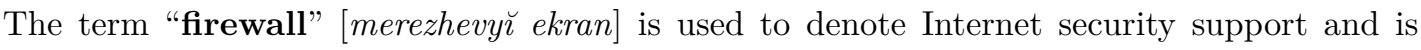
translated as [vohniana stina]. The use of this metaphor allows users and readers to visualize the method of protection and to believe in its effectiveness.

A figurative metaphor is used to name one of the most important parts of any computer - "motherboard", translated into Ukrainian as [materyns'ka plata]. The lexeme "mother" emphasizes the vital importance of this component for the operation of the entire system and relies on traditional associations with this word in the common vocabulary.

The term "tooltip" [pidkazka], also known as "infotip" or "hint", is a common graphical user interface element. Its metaphorical meaning gives readers or users a clear understanding of the term.

"An inforpreneur" [informatsiia + pidpryiemets] is interested in providing people with the specific information they need over the Internet. The metaphor refers to anyone who sells nonfiction eBooks, runs teleseminars (e.g. Skype or Zoom chats) or makes educational videos. In other words, anyone who is selling information over the web.

The second productive method of metaphorization is the rethinking of words from the source language, which leads to the creation of etymological metaphors. Let us study the special terminology of Latin and Greek origin, since it was these ancient languages that became the basis for the formation of most terminological units. A technical or scientific branch cannot function without vocabulary of Latin origin, due to its universality, tradition, and semantic and morphological stability. Latin is also widely used in the professional vocabulary of information technology. This is due to the internationality of IT terminology and its active use in various language areas. 
Latin and Greek word-formation components allow the use of English terms without translation. In most cases, a new notion is formed using well-known universal terms. Some examples follow.

The metaphor "accept"[vvodyty, pryımaty] and its derivatives acceptance, acceptable, etc. are based on the Latin verb "acceptare" [pryımaty, braty], which is derived from a combination of the prefix $a d$ - and the root capere [braty]. The same root became the source for the term "capacity" [potuzhnist $]$.

The lexeme "device" [prystriı] is used when nominating an item of hardware designed to perform a specific task. This shade of semantics is determined by the term's origin from the verb "dividere" [rozdiliaty, rozrizniaty] through Old French and Late Latin.

The professional language of information technology, however, is not only accurate but also figurative, which is associated with the active use of etymological metaphors in the process of forming terms. The metaphorization of Latin and Greek lexemes is based on functional analogy. For example, the well-known term "digital" [tsyfrovyı] goes back to the Latin word "digitus" [palets], which is a metaphor referring to the ancient way of counting. In English, in contrast to Ukrainian, the semantic connection is also emphasized by borrowing the outer shell of the word. In electrical engineering, the term "terminal" [vyvid, klema, kintseva pozytsiia] is actively used. The productive basis is the Latin word "terminus" [kamin' na mezhi, na kordoni], whose meaning was expanded by metaphorical transfer. The term "module" is used to refer to a standard unit of measure, a piece of software, etc., and is understandable without translation. Etymologically, it is a form of the Latin noun modus [mira, velychyna]. In Latin, the lexeme "modulus" was used in architecture to denote the scale of proportion, as well as in music with the meaning "rhythm" $[$ rytm, takt $]$. Metaphorization by an analogy made it possible to use the term in the IT sphere in English. The term "moderator" etymologically goes back to the verb "moderor" [strymuvaty, stavyty mezhu], which is the main function of a moderator on the Internet.

The peculiarity of understanding and interpreting IT metaphors lies in the fact that the English language continues to borrow foreign words for the nomination of new objects and phenomena and, at the same time, becomes a source of borrowings into other languages itself. The IT sphere demonstrates the results of globalization in the field of scientific and technical research, actively using English as an international language. Therefore, in the Ukrainian IT terminology system, translations of terms and metaphors are virtually unknown, but transliterations are widely used. This can be seen either in the professional language field or specific computer slang. The imagery and variety of computer slang are based on the use of English terms in a rethought, abbreviated, or transformed form. For example, the slang abbreviations "admin" (administrator) and "app" (application), the verb derived noun "login", and the metaphor "to surf/browse" the Internet [prohliadaty internet saïty] are widely known. Ukrainian language IT slang is characterized by even more unexpected linguistic features. For example, "батон" [baton] is a phonetic calque from the English "button" [knopka]. "Vasik" is a graphic calque of the English name of the Basic programming language, and "Telega" (which in Ukrainian means "a cart")) is a shortening from the social network Telegram. The metaphors "chatting" and "to chat" are used in both English and Ukrainian to denote online written communication. They are not translated into Ukrainian (the Ukrainian equivalents are not used), but only transliterated [chat, chatytysia]. In this way, new IT metaphors appear in Ukrainian. Some other examples are: "закинути в чат" [zakynuty v chat] (to throw in the chat), "загрузити у вайбер" [zahruzyty u valber] (download to Viber), etc that are considered to be culturally-relevant and intracultural. Such slang words are understandable either to a narrow circle of initiates or to those who can identify the principle of word formation based on the English term.

Both the motivation of the metaphor formation and its professional specifics must be taken into account while translating. Metaphor is one of the most effective tools for reflecting the surrounding reality in the process of cognition. Thus, metaphorization is possible due to a person's ability to compare his/her own experience with new, unidentified concepts. This is crucial for terminology in general, and professional vocabulary in particular. The main semantic focus of metaphors is association according to functions. The cognition and interpretation of metaphors are impossible 
without taking into account their context and professional characteristics. Digital translators are not able to recognize metaphorical meaning and can only offer the basic meaning enshrined in a commonly used dictionary.

\subsubsection{The Formatting of the Conceptual Metaphor "A COMPUTER AS A HUMAN} BEING" When using metaphor as a mechanism of cognitive processing to understand the complex changes occurring around them, a person uses the closest and most inherent concepts. This can be illustrated by the example of the general conceptual metaphor MACHINES ARE PEOPLE, which is related to the separate conceptual metaphor "A COMPUTER AS A HUMAN BEING" (cf. Figure 1).

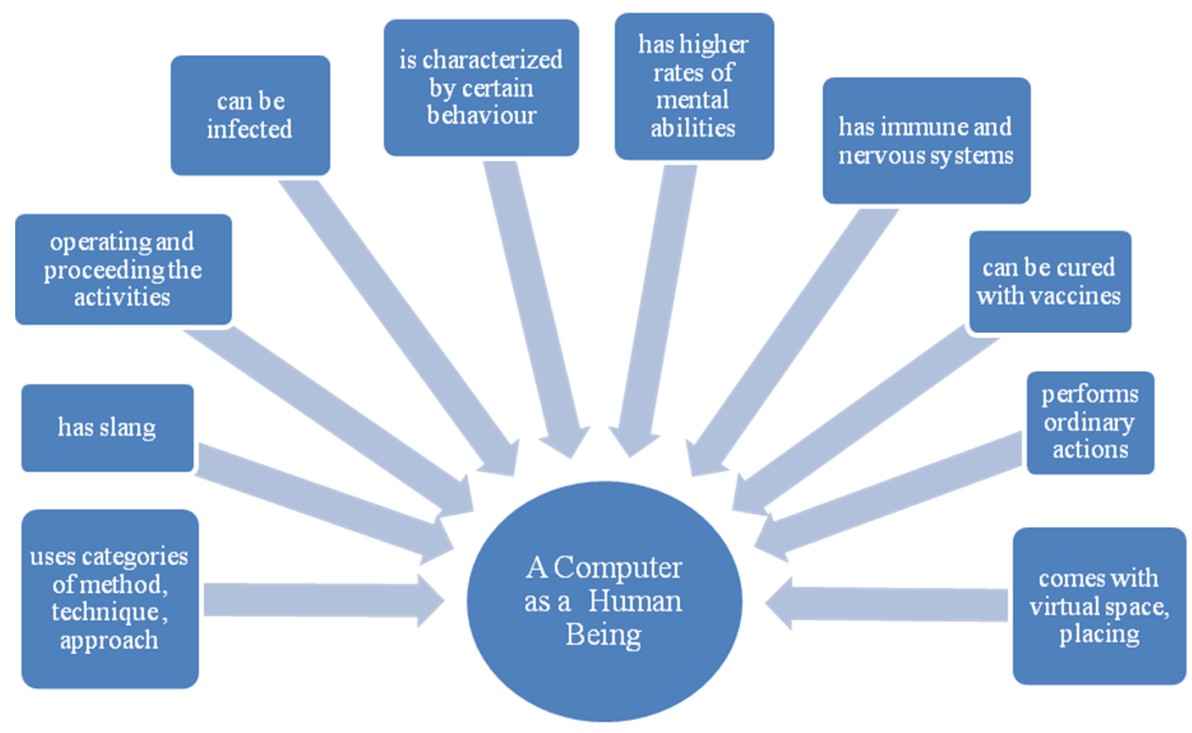

Figure 1. Conceptual metaphor "A COMPUTER AS A HUMAN BEING".

Consequently, a computer, like a human, can:

- get sick. If it takes more time than normal to react to a task or to operate, the computer is said to have a lag. If a computer does not respond to user interaction or does not work properly, it may be infected, it may have caught a bug, a virus, a worm, a Trojan horse, a logic bomb, etc.;

- be cured. If a computer is unwell, it should be cured to prevent the system from corrupting or destroying data. In such cases a virus detection system, a virus-scanning software, a vaccine, etc. can be used;

- have an immune and nervous system. We can compare the human immune system with the computer system because both of them protect either living organisms or computer systems from maleficent intrusion. Also, a neural circuit is loosely similar to an artificial neural network, so a computer can have an artificial immune system, a computer immune system, a neural network, a neural computing, a neural fuzzy logic system, etc.;

- be characterized by mental abilities. "Smart" is a mnemonic abbreviation, which was first described in George T. Doran's work (1981) in which he describes how to give criteria to set goals in project management. Primarily, this acronym (S.M.A.R.T.) stands for "specific, measurable, assignable, realistic, time-related", while later being used in computing as "SelfMonitoring Analysis And Reporting Technology". Nevertheless, an average person perceives this metaphorical construct towards a computer as a mental feature, e.g. intelligent, smart; 
- be characterized by certain behaviour, e.g. ill-behaved, well-behaved;

- perform ordinary actions like a human being:

- can have - authoring, flaming, teleconferencing, workgroup;

- can be fond of - adventure gaming, netsurfing, spamming, surfing the net, trolling, telecottaging;

- can make - crunch, hacking, telecommuting;

- have slang or jargon, which is characteristic of the professional activity of a person as well, e.g. technospeak, leetspeak;

- conduct professional activity. It can operate and conduct various activities, such as alpha testing, beta testing, reverse engineering, change management;

- use categories of a method, technique, and approach, e.g. dataflow, data warehousing, slice-and-dice, or even process messages, e.g. routing, tooltip;

- come with virtual space or a place, e.g. electronic newsroom, smart house, telecottage, virtual classroom.

In the group "Professional activity", the metaphors which denote various aspects of human financial and commercial activities, banking, and brokerage operations, conducted using the latest technologies in the field of IT, should also be mentioned: teleshopping, teleordering, telemarketing, electronic banking, frontend app, home banking, telebanking, telebetting, telebroking, virtual shopping, etc.

Metaphors in the IT sphere include the cognitive category of criminal activity, which generally conveys the concept of a crime committed with the help of new computer technologies: computer crime, software piracy, cracking, hacking, etc.

Metaphors reflect the adaptation process of the language system to the needs of communication by deepening the basic scientific concepts and forming new terms to denote modern scientific and technical realities: portable, workgroup, zooming, workshop, etc.

In the field of IT, metaphors are used to name the positions of people who work in this sphere: sysop, webmaster, webmeister, infopreneur, toolsmith, a-lifer, cyber lawyer, nanotechnologist, keyboarder, etc.

Metaphors in the IT sphere include the names of different types of jargon and slang, in particular: leetspeak, leet (the term "leet" is derived from the word "elite", used as an adjective to describe formidable prowess or accomplishment, especially in the fields of online gaming and computer hacking), technospeak (Collins English dictionary, 2018).

3.1.3 Findings We have seen that metaphors in the IT sphere are capable of creating new meanings and similarities, and thereby defining a new reality. Metaphorization is a source of language enrichment in the IT sphere. Metaphors in this sphere have a high level of informativeness that facilitates the understanding of new scientific facts. The basis of metaphorical transfers in IT terminology is functional and external similarity. The essential characteristics of metaphors are the following: (1) Images can "be read". They act like impressive stories on people's emotions. (2) They help make vague concepts clearer (of higher quality, more powerful, and more reliable). (3) They make texts easier to read and understand and more interesting.

IT metaphors are useful cognitive tools because they are involved in complex processes and serve as good reference points for various types of communication. As the data show, the diversity of IT metaphors reveals that English is a source of enrichment of the Ukrainian language in the IT sphere. The study has shown that this makes IT metaphors culturally relevant in an increasingly globalized world. Present empirical research assumes a universal conceptual understanding of IT metaphorical language which is of great demand for non-specialized readers, especially in the lockdown period during the Covid-19 pandemic. The fundamental change that occurs when scientifically established metaphors are used in popular scientific texts is their loss of status as scientific concepts. From an anthropocentric perspective, cultural diversity is complementary to the 
universality of IT metaphors. Thus, the metaphorization of IT language can overcome the limits of cross-cultural communication, when metaphors break down barriers to this communication.

The analysis of the examples taken from the English and Ukrainian databases reveals consistency in metaphorical projection from the human being domain. The conceptual metaphor "A Computer as a Human Being" is another example of a complex, highly structured phenomenon, regardless of cultural origin and scientific status.

3.2.1 Phase 2 - Data and Methodology The study of the psychological features of the conceptualization of the metaphor "A Computer as a Human Being" in the semantic space of the individual establishes the requirements for the sample formation of this empirical study. To model the metaphor in the speech consciousness of users, we considered the patterns of age development of the individual. The sample consisted of 1,432 people aged 13-22 (495 teenagers and 387 senior high school students of secondary school № 15 in the town of Rivne, Ukraine, and 550 second, third and fourth year students of the Faculty of Philology at Rivne State University of the Humanities). To achieve greater relevancy of results, the target sample was supplemented by extramural students of the Faculty of Philology at Rivne State University of the Humanities, aged 27-33 (in total 635 people), whose answers were considered as a model of the metaphor in the semantic space of the adult personality. The material of the study consisted of 6,837 answers and text fragments obtained from the respondents.

The integrative content of this psycholinguistic research led to the structuring of the research program according to the genetic method of systems research, which argues for the need to analyse the following: the ways of generating system formations; the patterns of their transformations; and the correlation between current and potential understanding. This method is designed to provide cognition and understanding of the metaphor "A Computer as a Human Being" as a complex entity operating under the influence of objective and subjective factors and, in turn, actively influencing them. In order to optimize the measurements of subjectogenesis, the convergence of three research vectors may be considered:

1. Clarifying the peculiarities of the lingualization of the conceptual sphere of the metaphor "A Computer as a Human Being" in the semantic space of users.

2. The study of the psycholinguistic features of the conceptualization of the metaphor "A Computer as a Human Being", which meets the requirements for the personal construct formation of Internet metaphors in today's cross-cultural environment.

3. Defining the age dynamics of the cognitive-semantic nature of the concept-sphere of the metaphor "A Computer as a Human Being" in the minds of the respondents.

When determining the lexical and semantic structural features of the concept-sphere of the metaphor "A Computer as a Human Being", the method of conceptual analysis was applied (Poliuzhyn, 2005). This method provides modelling and description of the relevant conceptual sphere. It is one of the means of the complex reconstruction of cognitive mechanisms of individual and/or collective consciousness, which mediate the formation and ordering of the linguistic picture of the world. The involvement of the conceptual analysis method in the psycholinguistic continuum determines not only the definition of the meanings of the studied concepts, but also the statement of the specifics of the conceptual field and the logical relations between its elements.

To achieve the research goal and to fulfil the tasks set for the respondents' understanding of the metaphor "A Computer as a Human Being", we used the following methods and psycho-diagnostic techniques adequate to the subject of research:

- a questionnaire (with open-ended questions), focused on identifying conscious and unconscious patterns in the development of the image of the metaphor "A Computer as a Human Being". These patterns represent the development of the cognitive-semantic component of linguistic consciousness in the transition from adolescence to adulthood (a new form of self-awareness, which has been called informational self-awareness) (Mykhal'chuk \& Ivashkevych, 2020a); 
- a non-standardized self-report entitled How is a computer similar to a living being?, used to study the semantic characteristics of the understanding of the metaphor "A Computer as a Human Being" (Mykhal'chuk \& Ivashkevych, 2020c);

- methods of free (narrative) description The ideal world of the functioning of metaphor in the information technology sphere (Mykhal'chuk \& Ivashkevych, 2020b). They provide an opportunity to identify the cognitive-semantic structures of the concept-sphere "A Computer as a Human Being" in the consciousness of respondents.

Table 2. Ranks of the construct "A Computer as a Human Being" in groups of respondents.

\begin{tabular}{|c|c|c|c|c|}
\hline \multirow[b]{3}{*}{ № $\quad$ Basic constructs } & \multicolumn{4}{|c|}{ Age groups of respondents } \\
\hline & $\begin{array}{l}\text { Teenagers } \\
(13-14 \text { years } \\
\text { old }) \mathrm{n}=495\end{array}$ & $\begin{array}{c}\text { Senior high } \\
\text { school students } \\
\begin{array}{c}(15-17 \text { years } \\
\text { old }) \mathrm{n}=387\end{array}\end{array}$ & $\begin{array}{c}\text { Full-time } \\
\text { students } \\
(18-22 \text { years } \\
\text { old) } \mathrm{n}=550\end{array}$ & $\begin{array}{c}\text { Extramural } \\
\text { students } \\
(27-33 \text { years } \\
\text { old) n=635 }\end{array}$ \\
\hline & \multicolumn{4}{|c|}{ Rank positions of the constructs } \\
\hline $\begin{array}{l}\text { 1. Similar in name, shape, essential } \\
\text { characteristics }\end{array}$ & 1 & 3 & 8 & 6 \\
\hline 2. Activity similarity & 5 & 1 & 11 & 10 \\
\hline 3. Similarity of forms and functions & 2 & 4 & 9 & 13 \\
\hline 4. Location similarity & 3 & 5 & 15 & 14 \\
\hline 5. Similarity of properties & 4 & 2 & 12 & 11 \\
\hline $\begin{array}{l}\text { 6. A Computer as a Human Being } \\
\text { uses categories of method, technique, } \\
\text { approach }\end{array}$ & 14 & 13 & 7 & 7 \\
\hline $\begin{array}{l}\text { 7. A Computer as a Human Being has } \\
\text { slang }\end{array}$ & 15 & 15 & 13 & 15 \\
\hline $\begin{array}{l}\text { 8. A Computer as a Human Being op- } \\
\text { erating and proceeding the activities }\end{array}$ & 13 & 14 & 1 & 8 \\
\hline $\begin{array}{l}\text { 9. A Computer as a Human Being can } \\
\text { be infected }\end{array}$ & 6 & 12 & 6 & 9 \\
\hline $\begin{array}{l}\text { 10. A Computer as a Human Being is } \\
\text { characterized by certain behaviour }\end{array}$ & 7 & 11 & 10 & 1 \\
\hline $\begin{array}{l}\text { 11. A Computer as a Human Being has } \\
\text { higher rates of mental abilities }\end{array}$ & 12 & 6 & 14 & 2 \\
\hline $\begin{array}{l}\text { 12. A Computer as a Human Being has } \\
\text { an immune and nervous system }\end{array}$ & 11 & 7 & 2 & 4 \\
\hline $\begin{array}{l}\text { 13. A Computer as a Human Being can } \\
\text { be cured with vaccines }\end{array}$ & 8 & 9 & 3 & 5 \\
\hline $\begin{array}{l}\text { 14. A Computer as a Human Being } \\
\text { performs ordinary actions }\end{array}$ & 9 & 8 & 5 & 3 \\
\hline $\begin{array}{l}\text { 15. A Computer as a Human Being } \\
\text { comes with virtual space, place }\end{array}$ & 10 & 10 & 4 & 12 \\
\hline
\end{tabular}

Primary data processing was conducted by the content analysis method, with the subsequent ranking of the significance of nominative blocks and the calculation of the statistical values of the obtained material. The Kolmogorov-Smirnov criterion $(\lambda)$ was used to determine the statistical differences of the obtained data from the normative distribution of the obtained results in the 
semantic field of the concept-sphere "A Computer as a Human Being". IBM SPSS Statistics 19 (Statistical Package for the Social Sciences) was used to summarize and analyse the empirical material. All variables were checked the normative distribution of their characteristic features, which indicates that the respondents understood the metaphor "A Computer as a Human Being".

The research programme suggests a framework in which the peculiarities of the actual use of lexical units of the semantic field metaphor "A Computer as a Human Being" may be clarified. This metaphor is defined as the most personalized system structure, which reflects the respondents' perception of the functioning of metaphors in the IT sphere.

3.2.2 Survey and Analysis The research examines the process and result of concept formation as a form of verbalization of conceptual content by enriching and/or expanding the semantic constant of the corresponding metaphor. The empirical research suggests the significance of differences in the conceptualization of the subjective image "A Computer as a Human Being" in the linguistic consciousness of subjects of different ages.

We analysed the respondents' answers to the questionnaire (e.g. "Why is the computer acting slower?", "How smart is your computer?", "Has your computer got a character?", "Can your computer feel your mood?", "Can your computer be angry at you?"), the cognitive-semantic characteristics (construal) of the subjective image "A Computer as a Human Being" presented in the texts of the non-standardized self-reports, How is a computer similar to a living being? (Mykhal'chuk \& Ivashkevych, 2020c), and the narrative descriptions The ideal world of the functioning of metaphor in the information technology sphere (Mykhal'chuk \& Ivashkevych, 2020b).

We distinguished the data as an interpretive, peripheral segment of the nominative field of the metaphorical concept "A Computer as a Human Being", which is a set of loosely structured predications that reflect the interpretation of individual conceptual features and their combinations in the form of species nominations of the semantic constant of the researchable concept and utterances, which correlate to the age group and the cross-cultural space.

The content analysis of the data provided an opportunity to determine the units of quantification of the concept-sphere and to identify basic constructs (indicators of the analysis). The findings of the psycho-diagnostic measurement of modelling patterns of the subjective image of "A Computer as a Human Being" in the compared groups of the sample frame are given in Table 2 .

The cognitive-semantic analysis and rank positions of the construct reveal a significant correlation between age and understanding of the metaphor. Firstly, the variability of the ratio of external (observable) and internal (related to the inner world) indicators of respondents' evaluation of the concept is noticeable. Teenagers (aged 13-14) and senior high school students (aged 15-17) adhere mainly to the figurative model of conceptualization, focusing on the cognitive-semantic features of the external profile. The first rank positions of these respondents are: "Similar in name, shape, essential characteristics" (I, III), "Similarity of forms and functions" (II, IV), "Location similarity" (III, V), "Similarity of properties" (IV, II), "Activity similarity" (V, I) in teenagers and senior high school students respectively. Generally, however, the semantic field of the concept-sphere in the worldview of adolescents revolves around the dichotomy of Image — Similarity and implies the understanding of the metaphor through the perception of similar characteristics.

The older full-time students (18-22 years old), on the other hand, are more focused on the conative (pragmatist, behavioural) model of identifying this concept sphere. Their first rank positions prove this: "operating and conducting activities" (I), "has an immune and nervous system" (II), "can be cured with vaccines" (III), "comes with virtual space, place" (IV), "performs ordinary actions" (V).

In contrast to the full-time students, the metaphor acquires more signs of subjectivity for the extramural students aged 27-33. For thus group, the first rankings are represented by the following characteristics: "is characterized by certain behaviour" (I), "has higher rates of mental abilities" (II), "performs ordinary actions" (III), "has an immune and nervous system" (IV), "can be cured with vaccines" (V). 
Qualitative analysis of the empirical material therefore makes it possible to claim that the responses in their age-based dynamics become more complete, knowledgeable, differentiated, and personalized. There is a much higher level of abstraction in the speech utterances of adolescents (in particular, nominative definitions of the "A Computer as a Human Being" metaphor are used more often), whose answers are more concise and compressed. The extramural students provided the most reasonable responses.

The Kolmogorov-Smirnov criterion $\lambda$ was used to conduct further analysis of the empirical material, as it helps to identify the accumulation in the dynamics of change when the sum of the accumulated differences $\left(d_{\max }\right)$ between estimates of different age groups will be a maximum.

The obtained value $\left(d_{\max }\right)$ in each case is an operationalized indicator of the emergence of a new type of semantic values (significantly larger or smaller) of the metaphor in older age groups, compared with the younger age groups. Hence, the qualitatively new forms of understanding of the metaphor seem to appear in its ontogenesis.

The Kolmogorov-Smirnov criterion $\lambda$ statistically confirms the differences between the obtained data and the normative distribution in the semantic fields of the constructs "Similar in name, shape, essential characteristics" (tendency to decrease use with age: $\left(d_{\max }=0.264, \rho<0.01\right)$ and "Similarity of forms and functions": $\left(d_{\max }\right)$ was recorded in the teenagers' responses $\left(d_{\max }=\right.$ $0.259, \rho<0.01)$ and senior high school students $\left(d_{\max }=0.197, \rho<0.05\right)$.

There are also differences in the semantic content of the following parameters: "has an immune and nervous system" (tendency to increase with the age) and "has higher rates of mental abilities" with $\left(d_{\max } 0.247(\rho<0.01)\right.$ and $0.186(\rho<0.05)$ respectively.

There is a significant difference between our prior scientific assumption and the obtained data in the categories "operating and conducting actions" $\left(d_{\max }=0.214, \rho<0.01\right)$, "comes with virtual space, placing" $\left(d_{\max }=0.263, \rho<0.01\right)$, and "can be infected" $\left(d_{\max }=0.180, \rho<0.05\right)$, in which the point of maximum accumulation of changes also falls on the students (18-22 years old).

The point of statistically significant accumulation of differences in the values of students aged 27-33 and schoolchildren also falls on the characteristics "performs ordinary actions" $d_{\max }=$ $0.255, \rho<0.01)$, "has immune and nervous systems" ( $\left.d_{\max }=0.241, \rho<0.01\right)$.

The empirical research therefore proves a statistically significant increase in the percentage of units of information associated with "internal" indicators for assessing the conceptual content of the lexeme metaphor "A Computer as a Human Being" (subjectivity, personification, anthropocentrism), and student age (18-22 years old) is a turning point $\left(d_{\max }\right)$ accumulation of changes) for its formation.

\section{Conclusions}

Comprehending the conceptualization of the metaphor "A Computer as a Human Being" in the semantic space of a user determines the understanding of the metaphor's modelling (reflecting the cognitive-semantic content of the conscious world order) in the context of the information technology sphere and language consciousness. By continuously interiorizing information flows and learning from experience, a user modifies the flows into appropriate concepts, which are logically combined in the cognitive-semantic space of the concept-sphere, marked by linguistic signs.

The understanding and cognition of the metaphor are especially relevant in adolescence and youth (aged 15-22). In this age group, the metaphor "A Computer as a Human Being" acquires much-needed internal, personalized, and subjective qualities and becomes the subjective component of personal formation. It then develops into a leading factor in changing the users' awareness of the IT sphere in general.

In the construction of the subjective understanding of the metaphor "A Computer as a Human Being" by schoolchildren and students, there is a transition from an empirical identification and awareness of mostly figurative (similar and "external") attributes to a generalization of internal, 
relevant, personified, and anthropocentric subsystems. These attributes meet the ontogenetic requirements for the construction of personal constructs in today's cross-cultural environment and form a core part of the concept metaphor "A Computer as a Human Being".

\section{References}

Aristotel'. (2000). Ritorika. Poètika (O. TSybenko \& V. Appel'rot, Trans.). Labirint.

Arutiunova, N. D. (1979). IAzykovaia metafora (sintaksis i leksika). In V. P. Grigor'ev (Ed.), Lingvistika i poètika (pp. 147-173). Nauka.

Blèk, M. (1990). Metafora. In Teoriia metafory: Sbornik (pp. 153-172). Progress.

Bogachyk, M., \& Bihunov, D. (2020). The structural-semantic features of computer terms in English. Cognitive Studies / Études cognitives, 2020(20), Article 2262. https://doi.org/10.11649/cs. 2262

Cohen, L. J. (1993). The semantics of metaphor. In A. Ortony (Ed.), Metaphor and thought (pp. 58-70). Cambridge University Press.

Colburn, T. R., \& Shute, G. M. (2007). Abstraction in computer science. Minds and Machines: Journal for Artificial Intelligence, Philosophy, and Cognitive Science, 17(2), 169-184. https://doi.org/10 .1007/s11023-007-9061-7

Collins English dictionary complete and unabridged (13 ${ }^{\text {th }}$ ed.). (2018). Collins.

Doran, G. T. (1981). There's a S.M.A.R.T. way to write management's goals and objectives. Management Review, Vol. 70, Issue 11, pp. 35-36.

Eco, U. (1984). Semiotics and the philosophy of language. Indiana University Press.

Gibbs, R., \& Matlock, T. (2010). Metaphor, imagination, and simulation. In R. Gibbs (Ed.), The Cambridge handbook of metaphor and thought (pp. 161-176). Cambridge University Press. https: //doi.org/10.1017/CB09780511816802.011

Gozzi, R., Jr. (1990). The computer "virus" as metaphor. ETC: A Review of General Semantics, 47(2), 177-180. https://www.jstor.org/stable/42577199

Indurkhya, B. (1992). Metaphor and cognition. Kluwer Academic Publishers. https://doi.org/10.100 7/978-94-017-2252-0

Knudsen, S. (2003). Scientific metaphors going public. Journal of Pragmatics, 35(8), 1247-1263. https: //doi.org/10.1016/S0378-2166(02)00187-X

Kocherhan, M. P. (2010). Zahal'ne movoznavstvo. Vydavnychy̆ tsentr "Akademiia".

Kövecses, Z. (2002). Metaphor: A practical introduction. Oxford University Press.

Kövecses, Z. (2015). Where metaphors come from: Reconsidering context in metaphor. Oxford University Press. https://doi.org/10.1093/acprof : oso/9780190224868.001.0001

Lakoff, G. (1987). Women, fire and dangerous things. University of Chicago Press. https://doi.org/10 $.7208 /$ chicago/9780226471013.001.0001

Lakoff, G. (1993). The contemporary theory of metaphor. In A. Ortony (Ed.), Metaphor and thought (pp. 202-251). Cambridge University Press. https://doi.org/10.1017/CB09781139173865.013

Lakoff, G., \& Johnson, M. (1980). Metaphors we live by. University of Chicago Press.

Littlemore, J., \& Low, G. (2006a). Figurative thinking and foreign language learning. Palgrave Macmillan. https://doi.org/10.1057/9780230627567

Littlemore, J., \& Low, G. (2006b). Metaphoric competence and communicative language ability. Applied Linguistics, 27(2), 268-294. https://doi.org/10.1093/applin/aml004

Mac Cormac, E. R. (1990). A cognitive theory of metaphor. MIT Press.

Mykhalchuk, N., \& Bihunova, S. (2019). The verbalization of the concept of "fear" in English and Ukrainian phraseological units. Cognitive Studies / Études cognitives, 2019(19), Article 2043. https: //doi.org/10.11649/cs.2043

Mykhal'chuk, N. O., \& Ivashkevych, E. E. (2020a). Anketa dlia vyvchennia rozuminnia uchniamy pidlitkovoho ta starshoho shkil'noho viku ta studentamy obrazu "Metafora: Komp'iuter iak zhyva istota". RDHU.

Mykhal'chuk, N. O., \& Ivashkevych, E. E. (2020b). Metodyka vil'noho (naratyvnoho) opysu "Ideal'nyı̆ svit funktsionuvannia metafory v informatsiı̌no-tekhnolohichnǐ sferi". RDHU.

Mykhal'chuk, N. O., \& Ivashkevych, E. E. (2020c). Nestandartyzovanyı samozvit "IAkym ie komp'iuter iak zhyva istota?". RDHU.

Ortega y Gasset, J. (1966). Obras completes: Vol. 2: Las dos grandes metáforas. Revista de oxidente. 
Ortony, A. (1993). Metaphor, language, and thought. In A. Ortony (Ed.), Metaphor and thought (pp. 1-16). Cambridge University Press. https://doi.org/10.1017/СB09781139173865.003

Poliuzhyn, M. M. (2005). Kontseptual'na systema iak bazove poniattia kohnityvnoï semantyky $\breve{~ t e o r i i a ~}$ movnoï osobystosti. In Problemy romano-hermans'koï filolohï (pp. 5-20). Lira.

Ricoeur, P. (2003). The rule of metaphor: The creation of meaning in language. Routledge. https: //doi.org/10.4324/9780203426616

Schmidt, C. M. (2009). Metaphor and cognition: A cross-cultural study of indigenous and universal constructs in stock exchange reports. Intercultural Communication, 5, 1-17.

Searle, J. R. (1993). Metaphor. In A. Ortony (Ed.), Metaphor and thought (pp. 83-111). Cambridge University Press. https://doi.org/10.1017/CB09781139173865.008

Szymańska, M. (2018). The coral of your lips, the stars of your eyes - the function of the genitive case in a particular kind of genitive metaphor compared to other semantic functions of this case (based on examples in the Polish language). Cognitive Studies / Études cognitives, 2018(18), Article 1617. https://doi.org/10.11649/cs.1617

Temmerman, R. (2000). Towards new ways of terminology description: The sociocognitive approach. John Benjamins Publishing Company. https://doi.org/10.1075/tlrp.3

Thibodeau, P. H., \& Boroditsky, L. (2013). Natural language metaphors covertly influence reasoning. PLoS ONE, 8(1), Article e52961. https://doi.org/10.1371/journal.pone.0052961

Wyatt, S. (2021). Metaphors in critical Internet and digital media studies. New Media E Society, 23(2), 406-416. https://doi.org/10.1177/1461444820929324

Zawisławska, M. A., \& Falkowska, M. H. (2018). All my sour-sweet days I will lament and love a comparative analysis of metaphors with the basic taste adjectives in Polish and English. Cognitive Studies / Études cognitives, 2018(18), Article 1675. https://doi.org/10.11649/cs.1675

The publication was financed at the authors' expense.

The authors declare that they have no competing interests.

All the authors participated equally in preparing conception and academic editing of this article.

3 This is an Open Access article distributed under the terms of the Creative Commons Attribution 3.0 PL License (http://creativecommons.org/licenses/by/3.0/pl/), which permits redistribution, commercial and non-commercial, provided that the article is properly cited.

() The Authors 2021

Publisher: Institute of Slavic Studies, Polish Academy of Sciences

Publishing history: Received 2020-12-26; Accepted 2021-03-26; Published 2021-10-11. 